Mots-clés : Biotechnologie. Identification des vecteurs. Détection de parasites. Résistance à insecticides. Lutte antivectorielle.

\title{
BIOTECHNOLOGY AS APPLIED TO VECTORS AND VECTOR CONTROL
}

\author{
S. E. O. MEREDITH*, A. A. JAMES**
}

\begin{abstract}
SUMMARY
Vector borne diseases remain some of the major public health problems in the developing world. In this review some of the cur-

rent applications of biotechnology to vectors and vector control and some of the possible future applications are discussed.
\end{abstract}

\section{RÉSUMÉ: La biotechnologie dans l'étude des vecteurs et au service de la lutte antivectorielle.}

Les maladies transmises par vecteurs représentent toujours un des problèmes les plus graves de la santé publique dans nombre de pays en développement. Dans la présente publication, nous nous proposons de passer en revue quelques-unes des méthodes de biotechnologie, aujourd'hui couramment employées dans l'étude de vecteurs et d'évoquer leur potentiel en vue de la future lutte antivectorielle.

\section{INTRODUCTION}

Before commencing a survey of current developements in the field of vector control, it seems appropriate to consider the scale and importance of the problem being tackled.

Insect-borne diseases remain some of the major public health problems of the developing world. Recent estimates indicate that mosquito, phlebotomid and simuliid transmitted diseases affect more than 500 million people (Strichler 1989, Barker et al. 1986, WHO 1987). Indeed malaria is still the second leading cause of child mortality due to infectious disease (Walsh 1989) and the incidence of arboviruses, notably dengue, and other vector-borne diseases continues to rise (Parasitology Today 1989).

To those involved in tropical diseases, these facts hardly come as news and the conclusion that more attention should be paid to vectors and vector control seems obvious. It comes as something of a disappointment to realize that in practice, the converse is true.

During the last two decades studies on vectors and vector control have declined. Increasingly, attention and money is being channeled into other areas such as molecular biology and cellular immunology, leaving research on vectors marginalised and underfunded. Much research has been

* Department of Medical Microbiology, University of Amsterdam, Meibergdreef 39, 1105 AZ Amsterdam, Holland.

** Department of Molecular Biology and Biochemistry, University of California, Irvine CA 92717, USA. focussed on chemotherapy, vaccine development and the biology of selected parasite species. Unfortunately, these efforts have had limited success in terms of the control of vector-borne diseases. Recent developments in the rapidly evolving fields of molecular genetics, biochemistry and immunology have rekindled interest in vector-borne diseases and specifically the possibilities of controlling the vector populations. It has been proposed that investigations of vector species with the tools of biotechnology may open new avenues for control of the diseases they transmit (Miller et al., 1987). In this review we discuss some of the current applications of biotechnology to vectors and vector control, and suggest possible future applications.

Before discussing the application of DNA technology it is pertinent to look at some of the problems involved.

\section{PROBLEMS IN IDENTIFICATION}

Accurate identification of vector species is the prerequisite that other studies are based on. Many insect vectors are now known to consist of complexes of isomorphic sibling species making precise identification of individual members difficult. By definition, sibling species are morphologically similar and thus the classical morphological methods are not applicable and the exploitation of other identification techniques has been necessary. Biochemical approaches such as isoenzyme analysis and cuticular hydrocarbons profiles are of value in some species (Miles 1978, Townson et al., 1987). However, the use of isoenzyme pat- 
terns is limited by the fact that the enzymes of analysis are often labile and need to be conserved at low temperatures generally only available in laboratories in developed countries. This makes the analysis of field caught material impractical especially when the insects cannot be colonized. Cuticular hydrocarbon analysis has been explored in the identification of populations, but is not readily applicable to individuals, and some of the variation in the hydrocarbon profiles are difficult to interpret with regard to speciation. Cytogenetic analysis of the banding sequences of polytene chromosomes from larval salivary glands or adult ovarian nurse cells is, to date, the most reliable means of speciating members of the Simulium damnosum complex and the Anopheles gambiae, An. maculipennis and Culex culifacies complexes (Townson et al. 1987, Collins et al. 1988). However, the use of polytene chromosomes is limited to certain sexual or developmental stages and thus the specific status of other stages can only be inferred.

\section{REQUIREMENTS FOR EFFECTIVE VECTOR CONTROL}

Effective application of any form of control measure must be based on a fundamental understanding/comprehension of the taxonomy, bionomics, ecology, and behavior of the vector species and its relationship to its host and environment. With this understanding it should be possible to carefully monitor and evaluate the effects of control measures on disease transmission and further implement and adjust them to achieve greatest efficiency.

Until the late 1960 s vector control, primarily through the use of insecticides was the principle approach to the management of vector-borne diseases. This initially successful means of disease control was made ineffective by the development of insecticide resistance in target populations. Efforts to switch to new and better chemical insecticides only resulted in vector populations eventually becoming resistant, often with phenotypes of multiple insecticide resistance. Ultimately the cost of production of new insecticides and the realization of the toxic effects of continued applications of certain insecticides on the local ecology made these efforts unmanageable. Thus recent efforts in the control of vector-borne diseases have focused away from the vector despite observations such as that of Bruce-Chwatt (1980) who stated, of malaria, that " control of mosquitos is undoubtedly the best method of protecting a community against the disease ».

\section{MOLECULAR APPROACHES TO VECTOR IDENTIFICATION AND CHARACTERIZATION}

Recombinant DNA techniques offer the potential of the most direct way of determining genetic composition, and thus finding unique differences in DNA composition that may be used for species diagnosis, investigation of evolutionary relationships, and specific vector-parasite interactions. The advantages of DNA diagnostic methods over the previously mentioned techniques include the stability of the DNA in desiccated or alcohol-preserved specimens (Collins et al., 1988, Post and Crampton 1988), and the applicability of the techniques to all life stages and both sexes. Table $I$ lists some of the techniques and applications of DNA diagnostic probes.

There are two general approaches used when looking for DNA sequences for species identification or genetic studies. The first is to isolate repeated, non-coding DNA sequences. When looked for, such sequences have been found in all eukaryotes. The second approach is to isolate multicopy gene families, for example the ribosomal RNA genes or the mitochondrial genome, or to identify some multicopy non-coding region like the species-specific DNA sequences found in the ribosomal RNA gene-spacer regions.

Non-coding, multicopy DNA falls into two broad classes, the highly repetitive sequences which can make up 10-25 \% of the genome (Piessens et al., 1987), and the middle repetitive sequences. The highly repeated sequences are most useful for diagnostics because of their abundancy and are thus the most likely sequences to be isolated when genomic libraries are differentially screened for species-specific probes. These sequences can evolve rapidly (Flavell 1986)

TABLE I. - An outline of applications

of molecular biology techniques to vector insects.

\begin{tabular}{lll}
\hline \multicolumn{1}{c}{ Technique } & \multicolumn{1}{c}{ Variation identified } & \multicolumn{1}{c}{ Potential uses } \\
\hline Southern blot & Absence/presence and location of restriction sites & $\begin{array}{c}\text { Characterization for systematics, population gene- } \\
\text { tics, identification }\end{array}$ \\
$\begin{array}{l}\text { Dot blotting } \\
\text { Squash blotting }\end{array}$ & $\begin{array}{l}\text { Nucleotide sequence abundance/absence } \\
\text { Nucleotide sequence abundance/absence }\end{array}$ & $\begin{array}{l}\text { Detection/identification, abundance of sequence } \\
\text { In situ hybridization }\end{array}$ \\
$\begin{array}{l}\text { Polymerase chain reac- } \\
\text { tion }\end{array}$ & $\begin{array}{l}\text { Nucleotide sequence presence/absence } \\
\text { Presence/absence specific sequences }\end{array}$ & Detection/identification \\
\hline
\end{tabular}


and the specific nucleotide sequences can vary between closely related species (Piessens et al., 1987, Erttmann et al., in press). The sequence variation can cause restriction fragment-length polymorphisms (RFLP), and the analysis of these or direct sequence comparisons can be useful in deciding taxonomic relationships. This approach was successfully used by Gale and Crampton (1989) who demonstrated that a combination of three highly repeated sequences allowed differentiation between four of the six species in the An. gambiae complex. Similarly, Post and Crampton (1989) cloned repetitive sequences from the $S$. damnosum complex that can be used to distinguish between the $S$. squamosum/vahensi and S. squamosum/sanctipauli groups. In addition, this strategy has been used to isolate species specific sequences for many of the vector-borne parasites such as Plasmodia, Leishmania and certain filarial species (Holmberg et al. 1987, Barker et al. 1986, Unnasch 1987 Piessens et al. 1987).

In addition to sequence specificity, variation in copy number of repeat sequences has also been used for species identification. McLain et al. $(1986,1987)$ used the variation in abundance of repeat families to investigate the relationship between members of the Aedes scutellaris group and the Ae. albopictus sub-group. The use of multicopy gene families as a method for species identification is made possible by the presence in each cistron of conserved coding region, a less conserved or variable spacer region (the nontranscribed spacer region, NTSP). These spacer regions are known to vary between species and thus could serve as markers (Collins et al., 1987). Collins et al. used a fragment from a rDNA cistron to differentiate between $A n$. gambiae s s., An. arabiense and An. melas by Southern analysis. Similarly, Ready et al., employed DNA polymorphism as a diagnostic marker for populations of Phlebotomus papatasi and for distinguishing between $P$. papatasi and eight other phlebotomid species. Analysis of ribosomal sequences can be useful in studying inter and intra-specific polymorphism, as in Ae. aegypti (Gale and Crampton 1989). In view of the fact that Southern analysis is necessary, these rDNA probes are not useful as potential field tools, or for large numbers of samples.

\section{DETECTION OF PARASITES IN VECTORS}

Another useful application of DNA diagnostic probes is in evaluation of the entomological inoculation rate and the typing of specific pathogens in their vectors. At present it is often difficult to identify the parasite species within the insect vector. Infected insects are determined by dissection of individuals, a time consuming task especially in cases where the inoculation rate is low. Various « squash blot " techniques for rapid assay of type and inoculation rate have been tried and some have reported the ability to detect single organisms, and single-copy genes in orga- nisms (Sim et al., 1989), but dissection of insect tissue prior to analysis seems to produce the most consistent results (Goff et al., 1988) making this technique not readily fieldadapted. Application of the species-specific filarial DNA probes to detection of parasitised vectors is more complicated due to the highly resistant nematode cuticle and the difficulties involved in breaking it open to release DNA (Dawkins and Spencer, 1989).

The development of the PCR, polymerase chain reaction, has alleviated the necessity for using diagnostic probes whose target is highly abundant. In this technique, unique primer DNA sequences are used to amplify diagnostic DNA fragments in the presence of a target, free deoxyribonucleotides, and a heat-stable DNA polymerase. Moser et al. (1989) were able to use this technique to detect Trypanosoma cruzi in infected reduviid bugs, demonstrating its efficacy. Although their target was in fact a repetitive element, single copy genes would work as well. This technique is a potentially powerful tool for evaluating insects that are infected with very few pathogens. In theory, a single target organism should be sufficient to register a positive signal.

\section{MONITORING OF INSECTICIDE RESISTANCE}

Although the use of insecticides as a means of control of arthropod vectors has decreased, there are still situations where it is the control method of choice. However, insecticide resistance of the target vector could jeopardize these efforts. Recombinant DNA technology can potentially be used to assay vector populations for the presence of resistance factors. In some cases, insecticide resistance is the result of amplification of certain genes, usually esterases, that increase the resistance of the insect to one specific or a group of, insecticides. Mouches et al. (1987) demonstrated a 200 -fold amplification of the esterase B-1 locus of Culex quinquefasciatus correlated with resistance to organophosphates. As mentioned above, DNA diagnostic probes can be used to quantify differences in DNA levels in insects, and could be used here to identify mosquitoes with amplified genes, and therefore potentially resistant to insecticides.

\section{ANTI-VECTOR VACCINES}

An intriguing prospect for vector control comes from efforts looking to reduce the tick burden on cattle. Recent work has shown that cattle immunized with antigens derived from whole ticks mount an immune response that ultimately results in the reduction in number of ticks feeding to repletion (Kemp et al., 1989). The specific antigen responsible for the effect appears to be a protein located in the plasma membrane of the tick gut cells. The isolation, 
cloning, and expression of this protein could provide a powerful vaccine against the tick. Similarly, it might be possible to identify proteins in the midguts of other vector insects that may make them vulnerable to specific antibodies. This strategy could be particularly effective in the transmission of diseases like malaria or filariasis where the death of the mosquito after the first blood meal would prevent transmission.

\section{GENETIC MANIPULATION OF VECTORS}

Recently there has been increasing enthusiasm for identifying genes for parasite refractoriness in vectors and means for transferring them between different vector species (Miller et al., 1987). The goal of this work is to produce geneticallyaltered vector insects that can be used in novel strategies for the control of infectious diseases (Curtis and Graves, 1988). The types of alterations envisioned include strains of vector arthropods that are refractory to parasite or viral infection. Strains of arthropods refractory to specific pathogens can be used in population replacement or dilution trials.

To achieve these goals, a number of technical and biological achievements must be realized. These achievements include understanding the nature of refractoriness to specific pathogens and developing efficient techniques to introduce and express foreign or engineered genes in vector species. In addition, population-based studies of the vectors are required to identify transmission conditions where this approach can best be utilized. Fortunately, unlike agricultural control of insects, often apparently minor perturbations in the vector population could have major effects on the transmission of diseases. As derived from MacDonald's (1952) analysis of vectorial capacity, minor changes in the longevity, feeding behavior, and in some specific cases, the vector competence of an insect species, could affect transmission to the extent that a cycle may be broken. However, it should be emphasized that each situation should be evaluated independently and the effects of a genetically altered insect release program modeled before it is undertaken.

Efforts to genetically engineer insect vectors have focused primarily on mosquitoes. DNA-mediated transformation of vector species has been aggressively pursued by a number of laboratories. These efforts have focused on obtaining germ-line transformants using the $\mathrm{P}$ transposable element isolated from Drosophila melanogaster. However, the P element appears to work only in D. melanogaster and a few closely-related species (O'Brochta and Handler, 1988), currently precluding its use in other insects. There have been three published reports of stable transformation of mosquitoes by microinjection of DNA into embryos (Anopheles gambia, Miller et al., 1987, Ae. triseriatus, McGrane et al., 1988, and Ae. aegypti, Morris et al., 1989). In all cases, the transformation events occured at low frequencies and most likely as a result of illegitimate recombination. These low frequencies make it difficult to routinely assay the expression of exogenous genes.

Efforts are now underway to identify transposable elements that are derived from the mosquitoes themselves. Endogenous DNA sequences that belong to the middle repetitive class, that by Southern analysis have different banding patterns between strains, appear to be extrachromosal during some part of their propagation, are transcribed into RNA, and have sequence similarities to known reverse transcriptase or transposase molecules are likely candidates for endogenous transposable elements. A number of such sequences have been identified in mosquitoes (Crampton et al., 1990), and it remains to be shown that these sequences are truly mobile before they can be used as possible transformation vectors.

Candidate refractory genes for introduction into mosquitoes fall into two types, endogenous genes that have been identified by classical genetics, and exogenous gene constructs designed and targeted at a specific pathogen. Several endogenous genes have been partially characterized, most notably the filariasis susceptibility/refractory locus of Ae. aegypti (McDonald and Ramachandran, 1965). To be useful, such genes must be dominant, completely penetrant, and have few, if any, unlinked modifiers. Unfortunately, none of the described genes meets all of these requirements. There are additional problems associated with using endogenous genes. As yet, there is no straightforward means of isolating genes with refractory phenotypes from vector species. Transposon-tagging or chromosomewalking techniques that are so handy in Drosophila melanogaster do not exist in any vector species. Therefore, it seems most likely that refractory genes will be engineered.

The search for suitable endogenous genes that could be modified to confer parasite refractoriness has prompted investigations of vector organs and tissues where significant interactions with pathogens take place. Studies of the insect immune system, salivary glands, midgut, and reproductive system are turning up likely candidate genes. The requirements for these genes are that they encode major proteins, and be (hopefully) tissue - and stage - specific. Using the promotors and enhancers of such genes, it should be possible to achieve abundant and targeted expression of hybrid genes.

The requirement for abundant expression ins obvious. If, however, genetically-altered insects strains are to be used in population replacement strategies, the expression of an introduced hybrid gene should not have a deleterious effect on their survival. Exogenous gene expression directed by tissue and stage-specific promotors will contribute less to the genetic load of a transformed insect than gene expression directed by promotors of genes expressed in every cell.

Up to now, there has been little effort to identify and 
isolate genes or DNA fragments that might affect pathogen development when expressed in vectors. This is largely due to lack of a direct way of testing a large number of fragments for those that work best. However, experiments with pathogens that infect mosquito cells in culture, for instance viruses, should soon identify likely antipathogen activities. Several types of introduced molecules could affect pathogens within target tissues. For example, antisense RNAs that form duplexes with essential viral transcripts, thereby preventing their translation, could be used to uncouple viruses in situ from host cell machinery. The expression of an antiviral activity like the one induced in Sindbis virus-infected Ae. albopictus cells (Riedel and
Brown, 1979) could produce a refractory strain. Furthermore, certain insect endogenous antimicrobial agents such as cercopins and attacins can be overproduced and evaluated as antipathogen activities. Indeed, Gwadz et al. (1989) have shown that injections of synthetic cecropin into mosquitoes can decrease the number of Plasmodium oocysts that develop.

\section{SUMMARY AND CONCLUSIONS}

The current applications of recombinant DNA techniques to arthropod vectors and to the detection of parasites in vectors are summarized in table 2 .

TABLE II $a$. - Application of DNA techniques to vector insects.

\begin{tabular}{|c|c|c|c|}
\hline \multicolumn{4}{|l|}{ IDENTIFICATION } \\
\hline An. gambiae s. 1 . & Collins et al. & 1987 & Am. J. Trop. Med. Hyg. 37, 37-41 \\
\hline \multirow{8}{*}{$\begin{array}{l}\text { An. dirus s. } 1 . \\
\text { Ae. albopictes } \\
\text { Ae. scutellaris } \\
\text { S. damnosum s. } 1 .\end{array}$} & Gale and Crampton & 1987 & Med. Vet. Ent. 1, 127-136 \\
\hline & Gale and Crampton & 1988 & Med. Vet. Ent. 2, 77-79 \\
\hline & Panyim et al. & 1988 & Am. J. Trop. Med. Hyg. 38, 47-49 \\
\hline & McLain et al. & 1987 & Hered. $58,373-381$ \\
\hline & McLain et al. & 1986 & Ann. Ent. Soc. Am. 79, 784-791 \\
\hline & Post and Crampton & 1988 & $\begin{array}{l}\text { Biosystematics of haematophagous Inse } \\
\text { Press 245-255 }\end{array}$ \\
\hline & Ready and Smith & 1987 & $\begin{array}{l}\text { In Leishmaniasis The Current Status } \\
\text { D. T. Hart) NATO ASI Series vol. } 16\end{array}$ \\
\hline & Ready et al. & 1986 & Trans. Roy. Soc. Trop. Med. Hyg., 8 \\
\hline \multicolumn{4}{|l|}{ ChaRACterisation } \\
\hline \multirow[t]{2}{*}{ Ae. aegypti } & Gale and Crampton & 1989 & Eur. J. Biochem. 185, 311-317 \\
\hline & Black and Rai & 1988 & Genet. Res. Camb. 51, 185-195 \\
\hline \multicolumn{4}{|c|}{ Genetic Manipulation } \\
\hline \multirow{3}{*}{$\begin{array}{l}\text { An. gambiae } \\
\text { Ae. aegypti }\end{array}$} & Miller et al. & 1987 & Science $237,779-781$ \\
\hline & Crampton et al. & 1990 & Parasit. Today $6,31-36$ \\
\hline & Morris et al. & 1989 & Med. Vet. Ent. 3, 1-7 \\
\hline Ae. triseriatus & McGrane et al. & 1988 & Am. J. Trop. Med. Hyg. 39, 502-510 \\
\hline \multicolumn{4}{|c|}{ RESISTANCE MECHANISMS } \\
\hline Culex Species & Mouches et al. & 1987 & Science $233,778-780$ \\
\hline Evolution & Cross and Dover & 1987 & J. Mol. Biol. 195, 63-74 \\
\hline Reviewed by & Post and Crampton & 1987 & Parasitol. Today $3,380-383$ \\
\hline
\end{tabular}

TABle II b. - Application of DNA techniques to parasites in vectors.

\begin{tabular}{|c|c|c|c|}
\hline Plasmodium & Delves et al. & 1989 & Mol. Biochem. Parasit. 32, 105-112 \\
\hline Trypanosomes & $\begin{array}{l}\text { oLe-MoiYoi } \\
\text { Gibson et al. } \\
\text { McNamara et al. } \\
\text { Grieg and Ashall } \\
\text { Ready et al. } \\
\text { Rogers et al. }\end{array}$ & $\begin{array}{l}1987 \\
1988 \\
1989 \\
1987 \\
1988 \\
1989\end{array}$ & $\begin{array}{l}\text { Parasitol. Today 3, 371-374 } \\
\text { Parasitology 97, 63-73 } \\
\text { Acta Trop. 51, 55-61 } \\
\text { Parasitol. Today 3, 375-376 } \\
\text { Med. Vet. Ent. 2, 109-116 } \\
\text { Am. J. Trop. Med. Hyg. 434-439 }\end{array}$ \\
\hline Lymphatic filaria & Sim et al. & 1989 & Mol. Biochem. Parasit. 34, 127-134 \\
\hline $\begin{array}{l}\text { Rickettsia } \\
\text { in mosquito } \\
\text { in tsetse }\end{array}$ & $\begin{array}{l}\text { Townson et al. } \\
\text { Welburn and Gibson }\end{array}$ & $\begin{array}{l}1986 \\
1989\end{array}$ & $\begin{array}{l}\text { Trans. Roy. Soc. Trop. Med. Hyg. 80, } 343 \\
\text { Parasitology 98, } 81-84\end{array}$ \\
\hline $\begin{array}{l}\text { Anaplasma } \\
\text { in ticks }\end{array}$ & Goff et al. & 1988 & Proc. Nat. Acad. Sci. 85, 919-923 \\
\hline $\begin{array}{l}\text { Plague } \\
\text { in fleas }\end{array}$ & Thomas et al. & 1989 & J. Med. Ent. 26, 342-348 \\
\hline
\end{tabular}


The mosquito complexes and species have received most attention due to the relative ease of maintaining laboratory colonies, and also to their importance as vectors of malaria, arboviruses and bancroftian filariasis. DNA probes which differentiate between at least four members of the An. gambiae complex are available, and comparison between these and the biochemical and cytological methods give concordant results (Collins et al., 1988, $a, b$ ). Similarly, at least one member of the $A n$. dirus complex can be identified with a specific DNA probe.

Work on other vector complexes in which reliable means of differentiating adults are urgently required, is hampered by the difficulties encountered in maintaining laboratory colonies. However, there are some probes available for distinguishing members of the $S$. damnosum complex and certain Phlebotomid species.

Detection and species identification of parasites in vectors is an important aspect of epidemiological investigation before, during and post - control measures. In these kind of studies it is important that the assay be qualitative (all or nothing) rather than quantitative. It is also important that the parasite DNA is accessible to the DNA probe and that there is no inhibition from substances in vector tissues. Protozoan parasites of the Leishmania, Plasmodium, and Trypanosome groups can be reliably identified by squash blots with recombinant DNA probes (tableau II). Likewise, probes for Rickettsia, Yersinia and Anaplasma species have been successfully used to identify infected vectors.

The application of molecular biology to the investigation of the mechanisms and genetics of insecticide resistance have implications not only in the monitoring of resistance, but also to possible genetic manipulation of populations. Genetic control of insect populations has always been philosophically pleasing, but in practice has had little success (Crampton et al., 1990). However, recombinant DNA tools could open up aspects of vector biochemistry, genetics and physiology to genetic manipulation, and provide previously unanticipated opportunities for control of disease transmission.

Acknowledgments. - We thank Drs G. Van Eys, P. Wright and $\mathrm{Mr}$ G. Schoone for helpful comments on the manuscript and Mr F. Van Eysinga for editing assistance. Research support for SEOM is from the Science and Technology Programm of the Commission of European Communities grant no. ISSN-208, and for A. A. J. by the John D. and Catherine T. MacArther Foundation and the National Institutes of Health.

\section{REFERENCES}

Barker D. C., Gibson L. J., Kennedy W. P. K., Nasser A. A. A. A., Williams R. H. : The potential of using recombinant DNA speciesspecific probes for the identification of tropical Leishmania. Parasitology, 1986, 91, S139-S174.

Bruce-Chwatt L. J. : Essential Malariology. William Heinemann, Medical Books Ltd. The Alden Press Oxford, 1980.

Collins F. H., Petrarca V., Mpofu S., Brandling-Bennet A. D., Were J. B. O., Rasmussen M. O., Finnerty V. : Comparison of DNA probe and cytogenetic methods for identifying field collected Anopheles gambiae complex mosquitos. Am. J. Trop. Med. Hyg., $1988,39,545-550$.
Collins F. H., Mehaffey P. C., Rasmussen M. O., Brandling-Bennet A. D., Odera J. S., Finnerty V. : Comparison of DNA probe and isoenzyme methods for differentiating Anopheles arabiensis (Diptera: Culicidae). J. Med. Entomol., 1988, 25, 116-120.

Curtis C. F., Graves P. M. : Methods of replacement of malaria vector population. J. Trop. Med. Hyg., 1988, 2, 43-48.

Dawkins H. J. S., Spencer T. L. : The isolation of nucleic acid from nematodes requires an understanding of the parasite and its cuticular structure. Parasitol. Today, 1989, 5, 73-76.

Erttmann K. D., Meredith S. E. O., Greene B. M., Unnasch T. R. : Isolation and characterization of form specific DNA sequences of O. volvulus. Acta Leidensia (in press), 1990, 59, no $1+2$.

Flavell R. B. : Repetitive DNA and chromosome evolution in plants Philosophical Transactions of the Royal Society London, 1986, Series B 312, 227-242.

Gale K. R., Crampton J. M. : Use of a male specific DNA probe to distinguish female mosquitos of Anopheles gambiae species complex. Med. Vet. Entomol., 1988, 2, 77-79.

Gwadz R. W., Kaslow D., Lee J.-Y., Maloy W. L., Zasloff M., Miller L. H. : Effects of magainins and cercropins on the sporogenic development of malaria parasites in mosquitoes. Infect. Immun., 1989, 57, 2628-2633.

Holmberg M., Wigzell H. : DNA hybridization assays for detection of malarial sporozoites in mosquitos. Parasitol. Today, 1987, 3, 380.

Kemp D. H., Pearson R. D., Gough J. M., Willadsen P. : Vaccination against Boophilus microplus: Localization of antigens on tick gut cells and their interaction with the host immune system. Exp. Appl. Acarol., 1989, 7, 43-58.

MacDonald G. : The analysis of equilibrium in malaria. Trop. Dis. Bull., 1952, 49, 813-829.

MacDonald W. W., Ramachandron C. P. : The influence of the gene f (filarial susceptibility, Brugia malayi) on the susceptibility of Aedes aegypti to seven strains of Brugia, Wucheraria and Dirofilaria. Ann. Trop. Med. Parasitol., 1965, 59, 64-73.

Marchand R. P., Muzara A. E. P. : A field test of a biochemical key to identify members of the Anopheles gambiae group of species in north-east Tanzania. J. Trop. Med. Hyg., 1985, 88, 205-210.

Miles S. J. : Enzyme variations in the Anopheles gambiae giles group of species (Diptera: Culicidae). Bull. Entomol. Res., 1978, 68, 85-89.

Moser D. R., Kirchof L. V., Donelson J. E. : Detection of Trypanosoma cruzi by DNA amplification using the polymerase chain reaction. J. Clin. Microbiol., 1989, 27, 1477-1482.

O'Brochta D. A., Hindler A. M. : Mobility of P elements in drosophilids and non-drosophilids. Proc. Natl. Acad. Sci. USA, 1988, 85, 6052-6056.

Piessens W. F., McReynolds L. A., Williams S. A. : Highly repeated DNA sequence as species-specific probes for Brugia. Parasitol. Today, 1987, 3, 378-379.

Riedel B., Brown D. T. : Novel antiviral activity found in the media of Sinbis virus, persistantly infected mosquito cell cultures. $J$. Virol., 1979, 29, 51-60.

Strichler D. : How much malaria is there worldwide? Parasitol. Today, 1989, 5, 39-40.

Townson H., Post R. J., Phillips A. : Biochemical Approaches to Biochemical Taxonomy in: Blackflies, Ecology, Population Management and Annotated World List. Eds. Kim and Merritt. Pennsylvania State University, University Park and London, 1987.

Unnasch T. R. : DNA probes to identify onchocerca volvulus. Parasitol. Today, 1987, 3, 377-378.

Walsh J. A. : Disease Problems in the third world. In: Biomedical Science and the third World: Under the Volcano. Eds. Bloom B. R. and Cerami A. Ann. N. Y. Acad. Sci., 1989, 569, 1-16.

World Health Organisation : WHO expert committee on Onchocerciasis. Technical Report, 1987, Series 752.

(C) Masson, Paris 1990 